\title{
Roles and Responsibilities of Cataloging Managers: An Updated Study of Job Advertisements
}

Sian Brannon ${ }^{\mathrm{a}}$, Catherine Sassen ${ }^{\mathrm{b}}$, and Kevin Yanowski ${ }^{\mathrm{c}}$

${ }^{a}$ Collection Management, University of North Texas, Denton, United States; ${ }^{b}$ Collection

Management, University of North Texas, Denton, United States; ${ }^{c}$ Collection Management, University of North Texas, Denton, United States

Sian Brannon

Associate Dean for Collection Management

University of North Texas Libraries

ORCID ID: 0000-0001-6102-1428

Sian.Brannon@unt.edu

Catherine Sassen

Principal Catalog Librarian

University of North Texas Libraries

ORCID ID: 0000-0001-6188-4338

Catherine.Sassen@unt.edu

Kevin Yanowski

Department Head, Cataloging and Metadata Services

University of North Texas Libraries

ORCID ID: 0000-0002-3632-2445

Kevin.Yanowski@unt.edu

(Corresponding Author) 


\begin{abstract}
Content analysis of job advertisements provide a wealth of useful information related to job responsibilities and requirements. However, more recent information is needed to reflect current trends in job requirements for cataloging managers. The purpose of this research study was to determine employers' current expectations of cataloging managers in academic libraries. A second purpose was to examine how these expectations have changed since 2008. Through deductive thematic content analysis and a univariate approach, researchers identified new trends in cataloging manager job requirements, including additional technology responsibilities and a growing emphasis on diversity and inclusion.
\end{abstract}

Keywords: job advertisements, academic libraries, cataloging supervisors, cataloging management, supervision, management

\title{
Introduction
}

Researchers in library and information science (LIS) have devoted considerable attention to content analysis studies of job advertisements (Harper, 2012). Many of these studies concern cataloging positions (Kim \& Angnakoon, 2016). Research findings from these studies provide several benefits. Job seekers may use information about employers' expectations to refine their skill sets to be more competitive in the job market (Harper, 2012). LIS educators may use this information to shape the curricula to help their graduates meet needs in the workforce (HallEllis, 2015). Library administrators may use this information to refine cataloging department operations and to create professional development opportunities for their employees (Hall-Ellis, 
2015). Job advertisement studies also may illustrate how position requirements have changed over time (Harper, 2012).

Although many LIS content analysis studies have concerned cataloging job descriptions, only two have focused on cataloging manager positions (Hall-Ellis, 2006b; Zhu, 2008). Cataloging departments have experienced many changes since the most recent article on this topic was published in 2008 , and it is reasonable to expect that these changes have affected the roles of cataloging managers.

The purpose of this research study was to determine employers' current expectations of cataloging managers in academic libraries. A second purpose was to examine how these expectations have changed since 2008 .

This study was designed to answer the following research questions.

(1) What are the emerging job titles for cataloging manager positions?

(2) What are the emerging job responsibilities for cataloging manager positions?

(3) What are the minimum and preferred educational qualifications for cataloging manager positions?

(4) What are the minimum and preferred knowledge, skills, and experience qualifications for cataloging manager positions?

(5) What work experience is required for cataloging manager positions?

(6) What is the faculty status of cataloging manager positions?

(7) How have requirements changed for cataloging manager positions?

The following variables were analyzed in the study.

(1) Position title

(2) Position responsibilities 
(3) Minimum and preferred educational qualifications

(4) Minimum and preferred knowledge and skills

(5) Minimum and preferred work experience

(6) Faculty status and tenure track conditions

\section{Literature Review}

The primary purpose of content analysis studies of cataloging job advertisements is to examine position requirements and responsibilities. However, they vary greatly in scope and emphasis. The intent of this literature review is to provide an overview of these content analysis studies. Studies limited to cataloging manager jobs are covered in more detail because they correspond to the focus of the present research study.

\section{Catalog Librarian Job Advertisement Studies (Not Limited to Managers)}

Time periods covered by these studies differ considerably. Many of them cover a relatively short period, such as one year (Deeken \& Thomas, 2006; Hosoi, 2000; Lack, 2001), two years (Ellero, 2014; Turner, 2020) or three years (Reeves \& Hahn, 2010). However, a few studies have covered ten years or more to track how job requirements have changed over time (Chaudhry \& Komathi, 2001; Copeland, 1997; Dieckman, 2018; Hall-Ellis, 2015; Xu, 1996; Zhang, 2008).

Although assessing the demand for catalog librarians is the subtext of many studies, several have been conducted to place this topic at center stage. These studies include one concerning the demand for catalogers in the United Kingdom (Towsey, 1995); one comparing demand in the United Kingdom with that in the United States (Towsey, 1997); and one investigating the demand for serials catalogers from 1980 to 1995 (Copeland, 1997). 
Some researchers have emphasized the implications of cataloging job requirements for library school curricula (Hall-Ellis, 2005, 2006a, 2006b, 2008, 2015; Lussky, 2008; Park \& Lu, 2009; Park, Lu, \& Marion, 2009; Reeves \& Hahn, 2010; Sibiya \& Shongwe, 2018). Another aspect of graduate library education for catalogers was addressed by Palmer (1992), who reported that he was able to motivate students to learn cataloging skills by sharing cataloging job advertisements with them.

Populations researched in cataloging job advertisement studies vary widely. In some cases, populations have been limited to academic libraries (Deeken \& Thomas, 2006; Hosoi, 2000; Lack, 2001; Lussky, 2008), while in others they were not limited by type of library (HallEllis 2008; Palmer, 1992). Populations also have been limited to entry-level positions (Hall-Ellis, 2005, 2006a, 2015; Reeves, 2010; Turner, 2020). Although many studies have concerned catalogers in American libraries, others have pertained to catalogers in other countries, including South Africa (Sibiya \& Shongwe, 2018) and the United Kingdom (Towsey, 1995, 1997). Several studies have compared requirements for catalogers with those for librarians in other areas, such as public services or reference (Beile \& Adams, 2000; Reser \& Schuneman, 1992; Xu, 1996).

Some studies have been limited by cataloging specializations, including serials (Copeland, 1997; Dieckman, 2018; Kwasik, 2002; Mueller \& Mering, 1991) and special collections (Russell, 2003). Other studies have been limited to specializations which may include cataloging responsibilities, such as technical services administration (Zhu, 2009) and library discovery (Ellero, 2014). Two studies have focused on foreign language skills (Beall, 1991; Zhang, 2008). The effects of emerging responsibilities have been investigated in studies concerning non-MARC metadata (Geckle \& Nelson, 2017; Hall-Ellis, 2015; Han \& Hswe, 2010; Park \& Lu, 2009, Turner 2020) as well as information technology and library automation 
ROLES AND RESPONSIBILITIES OF CATALOGING MANAGERS

(Chaudhry \& Komathi, 2001; Furuta, 1990; Khurshid, 2003; Park, Lu, \& Marion, 2009; Xu, 1996).

\section{Cataloging Manager Job Advertisement Studies}

Two researchers have limited their studies to job advertisements for cataloging manager positions (Hall-Ellis, 2006b; Zhu, 2008). Zhu analyzed 44 academic library job advertisements from 2004 to 2006. She restricted her study to "positions with more than 50 percent of their job responsibilities managing traditional cataloging activities" (Zhu 2008, p. 53). Hall-Ellis (2006b, p. 61) took a different approach and limited her study to "90 technical services managerial position announcements posted among the 672 listings for catalog librarians" from September 2000 through August 2004. Hall-Ellis's study included advertisements from academic, public, and special libraries. In many cases she reported results by type of library.

Position titles were explored in both studies. Zhu (2008, p. 53) reported that the traditional position title found most often was "Head/Coordinator of Cataloging/Cataloging Services/Cataloging Management/Bibliographic Services.” Hall-Ellis (2006b, p. 83) identified "Head, Cataloging" and "Head (Library) Technical Services" as the job titles found most often for cataloging managers in academic libraries. The word featured in emerging position titles in both studies was "metadata".

Each researcher mentioned faculty status. Zhu reported that 20 of 44 (45.5\%) of postings in her study included information about tenure and faculty rank. Of these 20 postings, "16 stated that the positions were tenure-track and had faculty status (36.36\%) and 4 stated that the positions were not tenure-track faculty positions" (Zhu 2008, p. 59). Although Hall-Ellis 
mentioned faculty status as a feature of academic library job advertisements involving tenure, she did not specify the number of those jobs.

Both studies examined educational qualifications. In the Zhu study, $88.64 \%$ of 44 advertisements required a master's degree from an ALA-accredited program. She found only one advertisement requiring an additional graduate degree for promotion and tenure, while four others listed an additional advanced degree as preferred. Hall-Ellis limited her study to advertisements requiring a master's degree from an ALA-accredited program or a foreign equivalent, and reported that a majority required an additional graduate degree.

Required years of experience was another variable examined in both studies. The required number of years of supervisory experience in academic library job advertisements was mainly two to three years in the Zhu study, and three to five years in the Hall-Ellis study.

The same key competencies were identified in most of the advertisements in both studies. They included verbal and written communication skills, familiarity with cataloging resources, knowledge of bibliographic utilities, and knowledge of integrated library systems.

Emerging responsibilities were emphasized in the Zhu study, which covered advertisements from 2004 to 2006 . The most frequently occurring emerging responsibility was "Provide leadership for/manage/support metadata selection and handling for digital resources" (Zhu 2008, p. 59), found in $29.55 \%$ of the advertisements in the study. The second most common emerging responsibility was "Participate in digital initiatives," found in $15.91 \%$ of postings (Zhu 2008, p. 59). The earlier study by Hall-Ellis, which covered advertisements from 2000 to 2004, noted that "creating metadata for electronic resources" was mentioned in $6.8 \%$ of the postings (Hall-Ellis 2006b, p. 68). The Hall-Ellis study did not mention digital initiatives. 
Cataloging departments have been affected by many changes since the most recent cataloging manager job advertisement study was published in 2008 . These changes concern new and revised cataloging standards, linked data, and digital library initiatives. Furthermore, librarians are increasingly focused on collaboration, assessment, equity, diversity, and inclusion. Cataloging managers must respond to these changes if they are to be effective administrators. The studies discussed in this literature review provided a wealth of useful information when they were published, but more recent information is needed to reflect current trends in job requirements for cataloging managers. The present study was designed to fill this gap.

\section{Methodology}

Research design for this study follows the methods used in Zhu's analysis of "the head of cataloging position in academic libraries" (2008). Variables of analysis are:

- Position title

- Faculty status (if available)

- Position responsibilities

- Desired work experience (years)

- Minimum degree required

- Preferred degree attainment

- Minimum skills/knowledge/abilities

- Preferred skills/knowledge/abilities

\section{Data Collection}


Researchers employed non-probability purposive sampling, visiting several job sites and email listserv archives in search of job postings. Final sources included the AUTOCAT list, HigherEdJobs.com, IUG job listings, OCLC-CAT list, ALCTS Metadata Interest Group list, and the Metadata Standards list. The criteria for inclusion of an advertisement in the study were: posted from 2015 to 2020, for an academic library (including law or medical), and in the United States or Canada. As Zhu stated, "to be chosen for the study, the advertisement had to include some wording to indicate that the position was for a cataloging head, cataloging coordinator, or a cataloging supervisor" (2008). The current research, however, also includes postings discussing metadata management and technical services in general, as long as the position relates management of cataloging.

Initially, 61 postings were identified, downloaded, and discussed by all researchers. Three duplicates were removed, and 29 were excluded due to their incompleteness, as they were missing information related to desired variables of study. This resulted in final sample size of 29 postings for analysis. Each researcher took a subset of the job postings and copied the textual content to an Excel spreadsheet.

\section{Data Analysis}

Two of the researchers employed deductive thematic content analysis, starting with a predetermined variable list and extracting associated data. After an initial comparison related to specific variables, researchers determined a $90 \%$ inter-coder reliability rate. Researchers took a univariate approach, compiling frequencies of variable appearance in the job postings, and calculating corresponding percentages. 


\section{Results and Discussion}

Results and related discussion are presented below, following the categories and order of Zhu's (2008) article. There are a few categories that are not included due to nonexistence of related content in the currently studied position advertisements: "Reporting Lines" (not specified), "Unit Responsibilities" (usually contained in position responsibilities), and "Salary" (generally, "commensurate with experience").

A total of 29 job postings between 2015 and 2020 were analyzed. Their annual distribution is listed in Table 1 and their distribution by state is in Table 2. Sources of advertisements are provided in Table 3 .

\begin{tabular}{|l|l|}
\hline Year & No. of Ads \\
\hline 2015 & 4 \\
\hline 2016 & 2 \\
\hline 2017 & 3 \\
\hline 2018 & 7 \\
\hline 2019 & 5 \\
\hline 2020 & 8 \\
\hline Total & $\mathbf{2 9}$ \\
\hline
\end{tabular}

Table 1. Date of posting.

\begin{tabular}{|l|l|}
\hline State/Province & No. of Ads \\
\hline Colorado & 1 \\
\hline Connecticut & 1 \\
\hline Florida & 3 \\
\hline Indiana & 2 \\
\hline Iowa & 1 \\
\hline Louisiana & 1 \\
\hline Massachusetts & 1 \\
\hline Michigan & 1 \\
\hline Minnesota & 1 \\
\hline Mississippi & 1 \\
\hline New York & 4 \\
\hline Ohio & 1 \\
\hline Pennsylvania & 1 \\
\hline Rhode Island & 1 \\
\hline Texas & 4 \\
\hline
\end{tabular}




\begin{tabular}{|l|l|}
\hline Virginia & 3 \\
\hline Washington, DC & 2 \\
\hline
\end{tabular}

Table 2. Location of position.

\begin{tabular}{|l|l|}
\hline Source & No. of Ads \\
\hline ALCTS-Metadata Interest Group list & 4 \\
\hline AUTOCAT list & 15 \\
\hline HigherEdJobs.com & 5 \\
\hline Innovative Users Group job listings & 1 \\
\hline Metadata Standards list & 1 \\
\hline OCLC-CAT list & 3 \\
\hline
\end{tabular}

Table 3. Source of job advertisements.

\section{Position Titles}

Zhu's "Traditional Titles" included those that referenced "bibliographic services/access," "monographic cataloging," "print management," or referenced a specific type of cataloging, namely original, adaptive, and complex. Their "Emerging Titles" included "metadata" positions and combined departments, such as positions that served as the head of cataloging and acquisitions, as well as mentions of "digital resources" (2008). In contrast, more recent positions (see Table 4) have lesser variety in title. What was considered emerging in 2008 is now the most used position title. Current emerging titles include reference to discovery, systems, and content as a whole.

\begin{tabular}{|l|l|l|}
\hline Position Titles & No. of Ads & $\%$ \\
\hline Traditional Titles & & \\
\hline Head/Coordinator of Cataloging and Metadata Services & 10 & $34.48 \%$ \\
\hline Head/Director of Metadata Services/Management & 5 & $17.24 \%$ \\
\hline Head/Coordinator of Cataloging/Cataloging Services & 4 & $13.79 \%$ \\
\hline Head/Director/Coordinator of Technical Services & 4 & $13.79 \%$ \\
\hline Head of Technical Services and Acquisitions & 1 & $3.45 \%$ \\
\hline Manager of Monographic Cataloging Latin Script Unit & 1 & $3.45 \%$ \\
\hline Emerging Titles & & \\
\hline Administrator of Cataloging/Systems & 1 & $3.45 \%$ \\
\hline Director of Content Management & 1 & $3.45 \%$ \\
\hline
\end{tabular}




\begin{tabular}{|l|l|l|}
\hline Head of Metadata and Discovery & 1 & $3.45 \%$ \\
\hline Metadata and Content Services Department Head & 1 & $3.45 \%$ \\
\hline
\end{tabular}

Table 4. Position titles.

\section{Position Responsibilities}

\section{Traditional Responsibilities}

For the most part, Zhu's traditional groupings were also present in current postings. Supervising librarians appeared in $89.7 \%$ of the postings and developing policies and procedures appeared in $75.9 \%$ (see Table 5). However, one interesting discovery is that highly ranked responsibilities in Zhu's article dropped off considerably in the current postings. Zhu found "Serve on committees and task forces" in $25.0 \%$ of their postings whereas it only appeared in $10.3 \%$ of the current postings. Zhu also found "Work with collection development" listed in $15.9 \%$ of their posting (2008), but the same was only found in $3.5 \%$ currently.

The drop in committee and task force language can be seen as a shift in the general expectations of academic librarians. Service is now simply part of the job and no longer an exception that has to be listed. The drop in work with collection development can be seen as more unusual, but it could also speak to libraries in general having smaller departments that just have to work together to get things done. It should also be noted that quality control and project prioritization are listed in the current postings but not in Zhu's. They are marked with an asterisk $(*)$.

\begin{tabular}{|l|l|l|l|l|}
\hline Traditional Responsibilities & No. of Ads & \% & Zhu \% & Diff \\
\hline $\begin{array}{l}\text { Supervise/hire/train/evaluate staff and/or } \\
\text { librarians }\end{array}$ & 26 & $89.66 \%$ & $86.36 \%$ & $3.30 \%$ \\
\hline $\begin{array}{l}\text { Develop and implement policies and } \\
\text { procedures for the unit }\end{array}$ & 22 & $75.86 \%$ & $59.09 \%$ & $16.77 \%$ \\
\hline $\begin{array}{l}\text { Participate in system-wide planning/broader } \\
\text { management/policy decisions }\end{array}$ & 14 & $48.28 \%$ & $31.82 \%$ & $16.46 \%$ \\
\hline
\end{tabular}




\begin{tabular}{|l|l|l|l|l|}
\hline $\begin{array}{l}\text { Perform original cataloging/complex copy } \\
\text { cataloging }\end{array}$ & 14 & $48.28 \%$ & $31.82 \%$ & $16.46 \%$ \\
\hline Prepare management reports/statistics & 12 & $41.38 \%$ & $15.91 \%$ & $25.47 \%$ \\
\hline Serve as liaison to/collaborate with other units & 10 & $34.48 \%$ & $34.09 \%$ & $0.39 \%$ \\
\hline $\begin{array}{l}\text { Maintain professional contribution } \\
\text { (publications/services/etc.) }\end{array}$ & 9 & $31.03 \%$ & $15.91 \%$ & $15.12 \%$ \\
\hline $\begin{array}{l}\text { Represent the library in } \\
\text { local/regional/national groups }\end{array}$ & 8 & $27.59 \%$ & $9.09 \%$ & $18.50 \%$ \\
\hline Create a positive work environment & 7 & $24.14 \%$ & $6.82 \%$ & $17.32 \%$ \\
\hline $\begin{array}{l}\text { Stay abreast of national trends and } \\
\text { developments in cataloging }\end{array}$ & 6 & $20.69 \%$ & $18.18 \%$ & $2.51 \%$ \\
\hline $\begin{array}{l}\text { Provide leadership for library's participation } \\
\text { in national cataloging programs }\end{array}$ & 5 & $17.24 \%$ & $18.18 \%$ & $-0.94 \%$ \\
\hline Coordinate and manage unit documentation & 5 & $17.24 \%$ & $11.36 \%$ & $5.88 \%$ \\
\hline Perform/Manage authority control & 4 & $13.79 \%$ & $20.45 \%$ & $-6.66 \%$ \\
\hline Perform complex database maintenance & 4 & $13.79 \%$ & $9.09 \%$ & $4.70 \%$ \\
\hline Support other cataloging agencies on campus & 4 & $13.79 \%$ & $2.27 \%$ & $11.52 \%$ \\
\hline Serve on committees and task forces & 3 & $10.34 \%$ & $25.00 \%$ & $-14.66 \%$ \\
\hline Serve as a resource person & 3 & $10.34 \%$ & $18.18 \%$ & $-7.84 \%$ \\
\hline Work with systems & 3 & $10.34 \%$ & $6.82 \%$ & $3.52 \%$ \\
\hline Stay abreast of/implement new technology & 2 & $6.90 \%$ & $18.18 \%$ & $-11.28 \%$ \\
\hline $\begin{array}{l}\text { Provide leadership in an environment } \\
\text { anticipated change }\end{array}$ & 2 & $6.90 \%$ & $6.82 \%$ & $0.08 \%$ \\
\hline Work with collection development & 1 & $3.45 \%$ & $15.91 \%$ & $-12.46 \%$ \\
\hline Work with acquisitions & 0 & $0.00 \%$ & $11.36 \%$ & $-11.36 \%$ \\
\hline $\begin{array}{l}\text { Work with public services/Be responsive to } \\
\text { the needs of public services }\end{array}$ & 0 & $0.00 \%$ & $6.82 \%$ & $-6.82 \%$ \\
\hline Allocate resources & 0 & $0.00 \%$ & $4.55 \%$ & $-4.55 \%$ \\
\hline $\begin{array}{l}\text { Develop partnerships with other research } \\
\text { libraries }\end{array}$ & 0 & $0.00 \%$ & $2.27 \%$ & $-2.27 \%$ \\
\hline Serve as the lead cataloger & 0 & $0.00 \%$ & $2.27 \%$ & $-2.27 \%$ \\
\hline Revise staff's contributed records & 3 & $0.00 \%$ & $6.82 \%$ & $-6.82 \%$ \\
\hline Oversee quality control of cataloging* & 2 & $6.90 \%$ & $\mathrm{NA}$ & $\mathrm{NA}$ \\
\hline Prioritize and balance multiple projects* & $\mathrm{NA}$ & $\mathrm{NA}$ \\
\hline
\end{tabular}

Table 5. Traditional Responsibilities. * Indicates new responsibility since Zhu article.

\section{Emerging Responsibilities}

The differences in emerging responsibilities between the current postings and Zhu's postings showcase the changing landscape of cataloging. Providing leadership in metadata and digital 
resources was found in $29.6 \%$ of Zhu's postings, but only $10.3 \%$ of current postings.

Alternatively, working with vendors was only found in $2.3 \%$ of Zhu's postings, but $24.1 \%$ of current postings (2008). The first example speaks to the fact that digital resources and nonMARC metadata are a part of everyday life in present-day academic libraries. The second example shows that because more digital and electronic resources are being cataloged by libraries, cataloging managers are working more directly with vendors. Additionally, the emerging responsibilities not found in Zhu's postings typically fall well outside the realm of just cataloging and managing. In most prevalent of these new responsibilities, "enhance discovery of materials," the researchers interpreted "discovery" to mean the use of discovery systems like Summon instead of just enhancing traditional catalog records. The new emerging responsibilities are marked with an asterisk $\left(^{*}\right)$.

\begin{tabular}{|l|l|l|l|l|}
\hline Emerging Responsibilities & No. of Ads & $\mathbf{\%}$ & Zhu \% & Diff \\
\hline Work with vendors & 7 & $24.14 \%$ & $2.27 \%$ & $21.87 \%$ \\
\hline Have reference duties at the reference desk & 5 & $17.24 \%$ & $6.82 \%$ & $10.42 \%$ \\
\hline Have liaison duty to an academic department & 4 & $13.79 \%$ & $4.55 \%$ & $9.24 \%$ \\
\hline $\begin{array}{l}\text { Provide leadership for/manage/support } \\
\text { metadata selection and handling for digital } \\
\text { resources }\end{array}$ & 3 & $10.34 \%$ & $29.55 \%$ & $-19.21 \%$ \\
\hline Perform non-MARC metadata cataloging & 3 & $10.34 \%$ & $4.55 \%$ & $5.79 \%$ \\
\hline Have bibliographic instruction duties & 2 & $6.90 \%$ & $6.82 \%$ & $0.08 \%$ \\
\hline Participate in digital initiatives & 1 & $3.45 \%$ & $15.91 \%$ & $-12.46 \%$ \\
\hline Have acquisition duties & 1 & $3.45 \%$ & $13.64 \%$ & $-10.19 \%$ \\
\hline Have collection development duties & 1 & $3.45 \%$ & $9.09 \%$ & $-5.64 \%$ \\
\hline Manage contract cataloging/outsourcing & 1 & $3.45 \%$ & $9.09 \%$ & $-5.64 \%$ \\
\hline Work with electronic resources librarians/staff & 1 & $3.45 \%$ & $6.82 \%$ & $-3.37 \%$ \\
\hline Manage vendor-created MARC records & 1 & $3.45 \%$ & $4.55 \%$ & $-1.10 \%$ \\
\hline Work with link resolver & 1 & $3.45 \%$ & $4.55 \%$ & $-1.10 \%$ \\
\hline Maintain URLs for digital resources & 1 & $3.45 \%$ & $2.27 \%$ & $1.18 \%$ \\
\hline Work with licensing librarians/staff & 1 & $3.45 \%$ & $2.27 \%$ & $1.18 \%$ \\
\hline $\begin{array}{l}\text { Participate in the development of federated } \\
\text { searching }\end{array}$ & 0 & $0.00 \%$ & $4.55 \%$ & $-4.55 \%$ \\
\hline $\begin{array}{l}\text { Contribute to creation of A-Z e-journal list in } \\
\text { OPAC }\end{array}$ & 0 & $0.00 \%$ & $2.27 \%$ & $-2.27 \%$ \\
\hline
\end{tabular}




\begin{tabular}{|l|l|l|l|l|}
\hline $\begin{array}{l}\text { Develop processing models in support of } \\
\text { collection development }\end{array}$ & 0 & $0.00 \%$ & $2.27 \%$ & $-2.27 \%$ \\
\hline $\begin{array}{l}\text { Enhance existing records for Open Archive } \\
\text { Initiative }\end{array}$ & 0 & $0.00 \%$ & $2.27 \%$ & $-2.27 \%$ \\
\hline Have bibliographer duties & 0 & $0.00 \%$ & $2.27 \%$ & $-2.27 \%$ \\
\hline $\begin{array}{l}\text { Lead the project to implement MFHD and } \\
\text { NISO holdings standards }\end{array}$ & 0 & $0.00 \%$ & $2.27 \%$ & $-2.27 \%$ \\
\hline Maintain the unit web site & 0 & $0.00 \%$ & $2.27 \%$ & $-2.27 \%$ \\
\hline $\begin{array}{l}\text { Manage offsite transfer operations with access } \\
\text { services }\end{array}$ & 0 & $0.00 \%$ & $2.27 \%$ & $-2.27 \%$ \\
\hline $\begin{array}{l}\text { Participate in exploring linkages among } \\
\text { disparate access engines }\end{array}$ & 0 & $0.00 \%$ & $2.27 \%$ & $-2.27 \%$ \\
\hline Participate in grant proposals & 0 & $0.00 \%$ & $2.27 \%$ & $-2.27 \%$ \\
\hline $\begin{array}{l}\text { Participate in improving access to serial } \\
\text { content }\end{array}$ & 0 & $0.00 \%$ & $2.27 \%$ & $-2.27 \%$ \\
\hline $\begin{array}{l}\text { Participate in the conceptual development of } \\
\text { information space }\end{array}$ & 0 & $0.00 \%$ & $2.27 \%$ & $-2.27 \%$ \\
\hline Enhance discovery of materials* & 3 & $10.34 \%$ & NA & NA \\
\hline Participate in disaster recovery efforts* & 2 & $6.90 \%$ & NA & NA \\
\hline Works with/oversees processing* & 2 & $6.90 \%$ & NA & NA \\
\hline Manage ILL document delivery* & 1 & $3.45 \%$ & NA & NA \\
\hline Update IP and EZProxy* & 1 & $3.45 \%$ & NA & NA \\
\hline Manage budget* & 1 & $3.45 \%$ & NA & NA \\
\hline Teach in information literacy program* & 1 & $3.45 \%$ & NA & NA \\
\hline
\end{tabular}

Table 6. Emerging Responsibilities. * Indicates new responsibility since Zhu article.

\section{Faculty Rank/Status}

Faculty rank or status was only mentioned in 10 of the 29 postings (34.5\%), which is lower compared to 20 of 44 (45.5\%) in Zhu's study. Of these, five were tenure-track, one was dependent on credentials, and three were clearly non-tenure-track. One position stated that the rank was administration (see Table 7). Nineteen advertisements had no mention of tenure or faculty status.

\begin{tabular}{|l|l|l|}
\hline Faculty Status & No. of Ads & $\mathbf{\%}$ \\
\hline Tenure-track & 4 & $40 \%$ \\
\hline $\begin{array}{l}\text { Tenure-track; Minimum requirements listed are those of the Librarian II } \\
\text { rank }\end{array}$ & 1 & $10 \%$ \\
\hline Non-tenure track & 3 & $30 \%$ \\
\hline
\end{tabular}




\begin{tabular}{|l|l|l|}
$\begin{array}{l}\text { Will be tenure track or non-tenure track, at variable rank, depending on } \\
\text { credentials }\end{array}$ & 1 & $10 \%$ \\
\hline Administrator & 1 & $10 \%$ \\
\hline
\end{tabular}

Table 7. Faculty status (in advertisements with faculty rank or status indicated).

\section{Required Qualifications}

The delineated qualifications that appeared in "Minimum" and "Preferred Qualifications/Requirements" portions of advertisements regarding education, work experience, and various skill types were extracted and organized in alignment with those appearing in Zhu's article. In the tables below, data are presented with the number of current advertisements containing the skills, the corresponding $\%$, and then the percentage of advertisements in which the skill appeared in Zhu's 2008 study, with a final calculation of the difference to indicate the change over time.

\section{Educational Requirements}

Education requirements were included in 28 of 29 postings (96.6\%). One advertisement included a preferred qualification of "an additional advanced degree." One position specifically required an American Library Association (ALA) accredited degree from the United States, with no indication of whether an equivalent international program would suffice. Interestingly, two positions allowed for the master's degree to be currently incomplete, with the stipulation that it be complete by the time of appointment/start date, which seems unusual for a cataloging manager role.

This assortment of educational requirements closely mirrors the variety Zhu found in 2008. As such, the standard still appears to be an ALA-accredited library/information science degree, although, one sign that the requirement of this master's degree requirement may be on 
the decline is that four of the $28(14.3 \%)$ postings with education requirements stated indicated that an equivalent combination of education and experience would suffice (see Table 8).

\begin{tabular}{|l|l|}
\hline Minimum Degree(s) & No. of Ads \\
\hline ALA-accredited Master's degree in Library/Information Science & 14 \\
\hline $\begin{array}{l}\text { ALA-accredited Master's degree in Library/Information Science, or its } \\
\text { equivalent }\end{array}$ & 5 \\
\hline $\begin{array}{l}\text { ALA-accredited Master's degree, or equivalent, at the time of } \\
\text { appointment }\end{array}$ & 2 \\
\hline $\begin{array}{l}\text { ALA-accredited Master's degree in Library/Information Science or } \\
\text { equivalent combination of advanced degree and relevant experience }\end{array}$ & 3 \\
\hline $\begin{array}{l}\text { ALA-accredited graduate degree or accredited graduate degree in } \\
\text { another appropriate discipline }\end{array}$ & 1 \\
\hline $\begin{array}{l}\text { MLS/MLIS or MI degree from an ALA-accredited U.S. school of } \\
\text { information or library science }\end{array}$ & 1 \\
\hline MLS degree (no accreditation specification) & 1 \\
\hline MLS degree or equivalent (no accreditation specification) & 1 \\
\hline
\end{tabular}

Table 8. Educational requirements.

\section{Relevant Work Experience}

Just over half of the currently analyzed advertisements indicated a specific time range for desired relevant cataloging or technical services experience. This ranged from two years (in three postings) to seven years (in one posting). The majority of advertisements containing stated time period of required experience indicate a desire for three years of cataloging or technical services experience (see Table 9). Even fewer, less than half, of the advertisements indicated desired years of experience in supervision or management (see Table 10).

For a cataloging manager position, it appears that the desired range of experience is one to five years, with the usual amount of desired experience falling between two and three years. A few postings indicated a time requirement for other experience, such as "at least three years of significant experience in acquisitions." These findings matched the ranges of experience in Zhu's 2008 study, although the 2008 findings included a much broader range of specific experience, 
such as the experience must have been in an academic or research library, must have included original cataloging, or that the supervisory experience must have been in a cataloging unit.

\begin{tabular}{|l|l|}
\hline Desired Years of Cataloging/Technical Services Experience & No. of Ads \\
\hline 2 years & 3 \\
\hline 3 years & 9 \\
\hline 4 years & 1 \\
\hline 5 years & 3 \\
\hline 7 years & 1 \\
\hline
\end{tabular}

Table 9. Cataloging/Technical Services Experience

\begin{tabular}{|l|l|}
\hline Desired Years of Supervisory/Management Experience & No. of Ads \\
\hline 1 years & 2 \\
\hline 2 years & 4 \\
\hline 3 years & 4 \\
\hline 5 years & 1 \\
\hline
\end{tabular}

Table 10. Supervisory/Management Experience

\section{Managerial Skills}

Managerial skills in Table 11 are presented in the same order as in the previous study. Currently, the qualifications appearing in the most advertisements are supervisory skills, collaboration, and organizational skills. Notable differences are that there are fewer requirements now for general administrative skills, teamwork, and knowledge of professional issues and trends. Items denoted with an asterisk $\left(^{*}\right)$ and NA did not appear in 2008, and these include the highly sought-after skills of collaboration, as well as negotiation, proactive-ness, the ability to work independently, and program assessment.

\begin{tabular}{|l|l|l|l|l|}
\hline Managerial Skills & No. of Ads & \% & Zhu \% & Diff \\
\hline Overall & 25 & $86.21 \%$ & $100.00 \%$ & $-13.79 \%$ \\
\hline Supervisory skills & 16 & $55.17 \%$ & $77.27 \%$ & $-22.10 \%$ \\
\hline Organizational skills & 11 & $37.93 \%$ & $22.73 \%$ & $15.20 \%$ \\
\hline Leadership skills & 9 & $31.03 \%$ & $18.18 \%$ & $12.85 \%$ \\
\hline Ability to work with diverse groups & 9 & $31.03 \%$ & $15.91 \%$ & $15.12 \%$ \\
\hline Training skills (staff development) & 8 & $27.59 \%$ & $15.91 \%$ & $11.68 \%$ \\
\hline Analytical skills & 8 & $27.59 \%$ & $13.64 \%$ & $13.95 \%$ \\
\hline
\end{tabular}




\begin{tabular}{|l|l|l|l|l|}
\hline Teamwork skills & 6 & $20.69 \%$ & $47.73 \%$ & $-27.04 \%$ \\
\hline Problem-solving skills & 6 & $20.69 \%$ & $15.91 \%$ & $4.78 \%$ \\
\hline Flexibility & 6 & $20.69 \%$ & $2.27 \%$ & $18.42 \%$ \\
\hline Planning and budgeting skills & 4 & $13.79 \%$ & $18.18 \%$ & $-4.39 \%$ \\
\hline $\begin{array}{l}\text { Ability to work flexibly in changing } \\
\text { environment and implement change }\end{array}$ & 4 & $13.79 \%$ & $11.36 \%$ & $2.43 \%$ \\
\hline Creativity & 4 & $13.79 \%$ & $9.09 \%$ & $4.70 \%$ \\
\hline Project management skills & 2 & $6.90 \%$ & $15.91 \%$ & $-9.01 \%$ \\
\hline Ability to manage multiple responsibilities & 2 & $6.90 \%$ & $9.09 \%$ & $-2.19 \%$ \\
\hline $\begin{array}{l}\text { Ability to adhere to rigorous accuracy and } \\
\text { thoroughness (attention to detail) }\end{array}$ & 2 & $6.90 \%$ & $2.27 \%$ & $4.63 \%$ \\
\hline Decision-making skills & 2 & $6.90 \%$ & $2.27 \%$ & $4.63 \%$ \\
\hline General administrative skills & 1 & $3.45 \%$ & $100.00 \%$ & $-96.55 \%$ \\
\hline Knowledge of professional issues and trends & 1 & $3.45 \%$ & $43.18 \%$ & $-39.73 \%$ \\
\hline $\begin{array}{l}\text { Ability to understand, assess, and use new and } \\
\text { emerging technologies }\end{array}$ & 1 & $3.45 \%$ & $9.09 \%$ & $-5.64 \%$ \\
\hline Personnel management skills & 0 & $0.00 \%$ & $25.00 \%$ & $-25.00 \%$ \\
\hline Time management skills & 0 & $0.00 \%$ & $4.05 \%$ & $-4.05 \%$ \\
\hline Coordination skills & 0 & $0.00 \%$ & $2.27 \%$ & $-2.27 \%$ \\
\hline Collaboration* & 12 & $41.38 \%$ & NA & NA \\
\hline Ability to work independently* & 3 & $10.34 \%$ & NA & NA \\
\hline Assessment of programs* & 2 & $6.90 \%$ & NA & NA \\
\hline Negotiation* & 1 & $3.45 \%$ & NA & NA \\
\hline
\end{tabular}

Table 11. Managerial skills. * Indicates new duty since Zhu article.

\section{Communication Skills}

Communication skills appeared in fewer current postings compared to 2008 (see Table 12).

However, the specific communication skills listed, such as expression, interpersonal, and foreign language skills appeared in approximately the same percentages of postings.

\begin{tabular}{|l|l|l|l|l|}
\hline Communication skills & No. of Ads & \% & Zhu \% & Diff \\
\hline Overall & 19 & $65.52 \%$ & $90.91 \%$ & $-25.39 \%$ \\
\hline Expression skills (oral and written) & 18 & $62.07 \%$ & $63.64 \%$ & $-1.57 \%$ \\
\hline Interpersonal skills & 10 & $34.48 \%$ & $31.82 \%$ & $2.66 \%$ \\
\hline Foreign language skills & 4 & $13.79 \%$ & $11.36 \%$ & $2.43 \%$ \\
\hline $\begin{array}{l}\text { Experience in procedures development and } \\
\text { writing documentation }\end{array}$ & 2 & $6.90 \%$ & $11.36 \%$ & $-4.46 \%$ \\
\hline
\end{tabular}

Table 12. Communication skills. 
Knowledge of Cataloging/Metadata Tools and Resources

As many librarians now use the term "metadata" to refer to components of MARC (or 'traditional') cataloging, and not just description related to Dublin Core, MODS, etc., the researchers deemed it necessary to combine the two, making it difficult to directly compare results to Zhu. Therefore Table 13 below has no comparison for issues and trends. Zhu's analysis did show that $100 \%$ of the earlier advertisements had "Cataloging experience," thus permitting a comparison.

Many newer cataloging activities and resources appeared in the current advertisements, including batch loading, RDA, BIBFRAME, FRBR, national cooperative cataloging programs, and linked data. These were not on the radars of many catalogers in 2008, but are more standard now. RDA knowledge was the most prevalent, appearing in $17.24 \%$ of advertisements.

Otherwise, MARC 21 knowledge was most requested cataloging skill.

\begin{tabular}{|l|l|l|l|l|}
\hline $\begin{array}{l}\text { Knowledge of Cataloging/Metadata Tools } \\
\text { and Resources }\end{array}$ & No. of Ads & \% & Zhu \% & Diff \\
\hline Overall & 26 & $89.66 \%$ & $100.00 \%$ & $-10.34 \%$ \\
\hline MARC 21 & 14 & $48.28 \%$ & $70.45 \%$ & $-22.17 \%$ \\
\hline $\begin{array}{l}\text { Non-MARC metadata schemes (Dublin } \\
\text { Core, ead, MODS, VRA Core, etc.) }\end{array}$ & 12 & $41.38 \%$ & $47.73 \%$ & $-6.35 \%$ \\
\hline Cataloging/metadata experience** & 10 & $34.48 \%$ & $100.00 \%$ & $-65.52 \%$ \\
\hline LC classification & 10 & $34.48 \%$ & $54.55 \%$ & $-20.07 \%$ \\
\hline LC subject headings & 9 & $31.03 \%$ & $56.82 \%$ & $-25.79 \%$ \\
\hline Issues and trends in cataloging/metadata & 7 & $24.14 \%$ & NA & \\
\hline AACR2 & 6 & $20.69 \%$ & $61.36 \%$ & $-40.67 \%$ \\
\hline Authority control & 6 & $20.69 \%$ & $29.55 \%$ & $-8.86 \%$ \\
\hline Special format cataloging & 6 & $20.69 \%$ & $25.00 \%$ & $-4.31 \%$ \\
\hline Original cataloging & 6 & $20.69 \%$ & $6.82 \%$ & $13.87 \%$ \\
\hline Foreign language material cataloging & 1 & $3.45 \%$ & $2.27 \%$ & $1.18 \%$ \\
\hline LC rule interpretations & 0 & $0.00 \%$ & $25.00 \%$ & $-25.00 \%$ \\
\hline Database maintenance & 0 & $0.00 \%$ & $6.82 \%$ & $-6.82 \%$ \\
\hline RDA* & 17 & $58.62 \%$ & NA & NA \\
\hline BIBFRAME* & 5 & $17.24 \%$ & NA & NA \\
\hline Linked data* & 5 & $17.24 \%$ & NA & NA \\
\hline
\end{tabular}




\begin{tabular}{|l|l|l|l|l|}
\hline Acquisitions* & 5 & $17.24 \%$ & NA & NA \\
\hline $\begin{array}{l}\text { NACO/SACO/PCC/CONSER/BIBCO } \\
\text { National cooperative cataloging } \\
\text { programs)* }\end{array}$ & 2 & $6.90 \%$ & NA & NA \\
\hline FRBR* & 2 & $6.90 \%$ & NA & NA \\
\hline Batch loading* & 1 & $3.45 \%$ & NA & NA \\
\hline Indexing* & 1 & $3.45 \%$ & NA & NA \\
\hline
\end{tabular}

Table 13. Knowledge of cataloging/metadata tools and resources. * Indicates new duty since Zhu article.

\section{Knowledge of Automated Cataloging Systems}

Recent job advertisement for cataloging manager positions certainly have less mentions of automated catalog systems (bibliographic utilities and automated library systems) as requirements, far fewer as compared to Zhu's findings. Only two of 29 postings included any mention at all (see Table 14), whereas over half of 2008's postings did. Perhaps this is due to the ubiquitous nature of these systems as a job requirement.

\begin{tabular}{|l|l|l|l|l|}
\hline Knowledge of Automated Cataloging Systems & No. of Ads & \% & Zhu \% & Diff \\
\hline Overall & 2 & $6.90 \%$ & $55.09 \%$ & $-48.19 \%$ \\
\hline Bibliographic utilities (OCLC, etc.) & 2 & $6.90 \%$ & $55.09 \%$ & $-48.19 \%$ \\
\hline Automated Library Systems & 1 & $3.45 \%$ & $52.27 \%$ & $-48.82 \%$ \\
\hline
\end{tabular}

Table 14. Knowledge of automated cataloging systems.

\section{Knowledge of Internet/Digital Systems}

In 2008, Zhu included Non-MARC metadata and trends/issues in metadata as part of internet and digital systems requirements, whereas the current researchers have included that in general (traditional) cataloging skills, as they are no longer emerging responsibilities (see Table 13). Very few current postings mentioned digital initiatives or networks, and one mentioned XML. A newer skill included in one current posting was knowledge related to discovery systems (see Table 15).

\begin{tabular}{|l|l|l|l|l|}
\hline Knowledge of IT/Digital Systems & No. of Ads & $\%$ & Zhu \% & Diff \\
\hline
\end{tabular}




\begin{tabular}{|l|l|l|l|l|}
\hline Overall & 2 & $6.90 \%$ & $61.36 \%$ & $-54.46 \%$ \\
\hline XML & 1 & $3.45 \%$ & $2.27 \%$ & $1.18 \%$ \\
\hline Digital initiatives/digital libraries & 0 & $0.00 \%$ & $11.36 \%$ & $-11.36 \%$ \\
\hline Networks/networking & 0 & $0.00 \%$ & $11.36 \%$ & $-11.36 \%$ \\
\hline Discovery systems* & 1 & $3.45 \%$ & NA & NA \\
\hline
\end{tabular}

Table 15. Knowledge of IT/digital systems. * Indicates new duty since Zhu article.

\section{Computing/IT Skills}

No current postings listed "General computer skills" or "Networks or networking" as a requirement, which follows Zhu's premise that this requirement is a given.

\section{Ranking of Required Skills/Knowledge by Demand}

The most prevalent requirements for skills or knowledge for a cataloging manager position in Zhu's 2008 publication were:

1. Management skills (100\%); Knowledge of cataloging tools and resources $(100 \%)$

2. Communication skills $(90.9 \%)$

3. Knowledge of Internet/Digital Systems (61.36\%)

4. Knowledge of Automated Cataloging Systems (54.55\%)

5. Computing/IT skills $(29.55) \%$

Similarly, the current study's most frequently appearing requirements are:

1. Knowledge of cataloging/metadata tools and resources $(89.66 \%)$

2. Managerial skills $(86.21 \%)$

3. Communication skills $(65.52 \%)$

The last three of Zhu's most required skills (internet/digital systems, automated cataloging systems, and computing/IT) each appeared in less than 7\% of more recent job 
postings. This is to be expected, as in the span of time between studies, internet and automated cataloging systems are the norm, and correspondingly, computer skills are considered a given. A number of new required skills appeared in the $2015-2020$ postings. In management, they include collaboration, appearing in $41.38 \%$ of postings, the ability to work independently (10.34\%), assessment of programs (6.9\%) and negotiation (3.45\%). Cataloging skills that did not appear in Zhu's findings include RDA (58.62\%), BIBFRAME (17.24\%), linked data (17.24\%), acquisitions (17.24\%), national cooperative cataloging programs (6.9\%), FRBR (6.9\%), batch loading (3.45\%) and indexing (3.45\%). Lastly, skills related to discovery systems were mentioned in one posting (3.45\%). These suggest new abilities and knowledge for job applicants to pursue and highlight.

\section{Preferred Qualifications}

About three-quarters of the recent position advertisements listed preferred qualifications. Many appear at about the same frequency as in Zhu's 2008 study. Experience with a variety of formats, experience with web technology (automated tools), project management skills, and experience in an academic or research library appeared in more postings. Acquisitions experience was the only qualification with a major decline, appearing in one-tenth fewer advertisements.

There were many new preferred qualifications as compared to 2008 (marked with an asterisk (*) in Table 16), and they correspond with some of the emerging skills indicated in Table 13 above. Experience with linked data is a new preferred qualification, appearing in onefifth of postings. This is followed by more technical skills, such as digital initiatives and coding. Other interesting preferred qualifications not found in 2008 are experience with electronic resource management, EZ Proxy, and system migration. 


\begin{tabular}{|c|c|c|c|c|}
\hline Preferred Qualifications & No. of Ads & $\%$ & Zhu \% & Diff \\
\hline Experience with a specific integrated library system & 11 & $37.93 \%$ & $31.82 \%$ & $6.11 \%$ \\
\hline $\begin{array}{l}\text { Experience cataloging a variety of types and formats } \\
\text { of materials }\end{array}$ & 7 & $24.14 \%$ & $6.82 \%$ & $17.32 \%$ \\
\hline $\begin{array}{l}\text { Experience working in an academic or research } \\
\text { library }\end{array}$ & 7 & $24.14 \%$ & $11.36 \%$ & $12.78 \%$ \\
\hline Knowledge of one or more foreign languages & 7 & $24.14 \%$ & $29.55 \%$ & $-5.41 \%$ \\
\hline Project management skills & 7 & $24.14 \%$ & $9.09 \%$ & $15.05 \%$ \\
\hline Supervisory experience/skills & 7 & $24.14 \%$ & $18.18 \%$ & $5.96 \%$ \\
\hline Experience with web technology (automated tools) & 6 & $20.69 \%$ & $4.55 \%$ & $16.14 \%$ \\
\hline $\begin{array}{l}\text { Experience/knowledge of non-MARC metadata } \\
\text { standards and services }\end{array}$ & 5 & $17.24 \%$ & $13.64 \%$ & $3.60 \%$ \\
\hline Experience with OCLC/RLIN & 4 & $13.79 \%$ & $11.36 \%$ & $2.43 \%$ \\
\hline Communication skills & 3 & $10.34 \%$ & $9.09 \%$ & $1.25 \%$ \\
\hline Demonstrating effective leadership & 3 & $10.34 \%$ & $4.55 \%$ & $5.79 \%$ \\
\hline $\begin{array}{l}\text { Experience with vendor-supplied records (including } \\
\text { batch processes) }\end{array}$ & 3 & $10.34 \%$ & $4.55 \%$ & $5.79 \%$ \\
\hline Training experience & 3 & $10.34 \%$ & $4.55 \%$ & $5.79 \%$ \\
\hline Experience with consortia & 2 & $6.90 \%$ & $9.09 \%$ & $-2.19 \%$ \\
\hline Ability to collaborate & 1 & $3.45 \%$ & $4.55 \%$ & $-1.10 \%$ \\
\hline $\begin{array}{l}\text { Ability to work effectively and collegially with } \\
\text { university faculty and library colleagues }\end{array}$ & 1 & $3.45 \%$ & $4.55 \%$ & $-1.10 \%$ \\
\hline $\begin{array}{l}\text { Experience with a national cooperative program } \\
\text { (PCC, BIBCO, NACO, SACO, or CONSER) }\end{array}$ & 1 & $3.45 \%$ & $6.82 \%$ & $-3.37 \%$ \\
\hline Experience with budgeting & 1 & $3.45 \%$ & $4.55 \%$ & $-1.10 \%$ \\
\hline Experience with Dewey & 1 & $3.45 \%$ & $4.55 \%$ & $-1.10 \%$ \\
\hline Knowledge of emerging technologies & 1 & $3.45 \%$ & $6.82 \%$ & $-3.37 \%$ \\
\hline $\begin{array}{l}\text { Record of scholarship (publications, presentations, } \\
\text { etc.) and professional service }\end{array}$ & 1 & $3.45 \%$ & $4.55 \%$ & $-1.10 \%$ \\
\hline Experience with acquisitions & 0 & $0.00 \%$ & $9.09 \%$ & $-9.09 \%$ \\
\hline Experience with linked data* & 6 & $20.69 \%$ & NA & NA \\
\hline $\begin{array}{l}\text { Experience with digital initiatives, such as } \\
\text { institutional repository, CONTENTdm* }\end{array}$ & 4 & $13.79 \%$ & NA & NA \\
\hline $\begin{array}{l}\text { Coding experience (Python, PERL, Javascript, SQL, } \\
\text { API development, etc.)* }\end{array}$ & 3 & $10.34 \%$ & NA & NA \\
\hline Experience with electronic resource management* & 3 & $10.34 \%$ & NA & NA \\
\hline $\begin{array}{l}\text { Knowledge of scholarly communication/open access } \\
\text { issues* }\end{array}$ & 3 & $10.34 \%$ & NA & NA \\
\hline Experience with system migration* & 2 & $6.90 \%$ & NA & NA \\
\hline Teamwork* & 2 & $6.90 \%$ & NA & NA \\
\hline $\begin{array}{l}\text { Experience at an urban, } \mathrm{HBCU} \text {, or minority serving } \\
\text { institution* }\end{array}$ & 1 & $3.45 \%$ & NA & NA \\
\hline Experience maintaining a local EZProxy* & 1 & $3.45 \%$ & NA & NA \\
\hline Experience negotiating with vendors* & 1 & $3.45 \%$ & $\mathrm{NA}$ & NA \\
\hline
\end{tabular}




\begin{tabular}{|l|l|l|l|l|}
$\begin{array}{l}\text { Experience preparing statistics and reports/data- } \\
\text { informed decision making* }\end{array}$ & 1 & $3.45 \%$ & NA & NA \\
\hline Experience working with bargaining unit staff* & 1 & $3.45 \%$ & NA & NA \\
\hline Knowledge of database design* & 1 & $3.45 \%$ & NA & NA \\
\hline
\end{tabular}

Table 16. Preferred qualifications. * Indicates new qualification since Zhu article.

\section{Additional Qualifications}

More recent cataloging manager job advertisements included a variety of desired skills and knowledge that were not mentioned at all in 2008. Table 17 reflects specific stated responsibilities, with institution names redacted, related to equity, diversity, and inclusion (EDI). Other interesting qualifications that did not fit into the categories discussed thus far include experience working with library data, the "ability to recommend solutions in areas not under direct supervision," a "general understanding of the external environment and how it affects academia in general and [school] in particular, including political, legal, environmental, educational, financial and social influences," those related to a commitment to student success, and, most ambitiously, "extensive functional knowledge and expertise in all aspects of own and related areas of [school], and pertinent interdependencies." It also serves to note that one school had a preferred qualification of experience in an urban, historically black college or university, or minority institution. It will be interesting to note if in the future, EDI responsibilities are less "emerging" and more of a given.

\section{EDI Responsibilities}

Ability to use knowledge, experience, awareness, and skills to advance [school's] commitment to diversity and inclusion, and to engage effectively with a broad spectrum of culturally diverse group

Demonstrated commitment to diversity and understanding of the contributions a diverse workforce brings to the workplace.

Demonstrated experience working in and fostering a diverse faculty, staff, and student environment or commitment to do so as a faculty member at [school] Demonstrates a strong commitment to promoting and enhancing diversity and inclusion Embraces and employs the diversity of individuals, cultures, values, ideas and communication styles in the achievement of common goals 
Fosters and environment of respect, dignity, and compassion that affirms and empowers all of its members (students, faculty, staff, outside organizations, others you provide service to) while striving for the highest ethical standards and social responsibility Models inclusive excellence through specific actions that support the college's diversity goals in the recruitment, hiring, and retention of talented and diverse faculty and staff

Team leader who fosters an inclusive, efficient, and collegial workplace

Table 17. EDI-related job responsibilities.

\section{Conclusion}

While the researchers' analysis of job postings and comparison to Zhu's previous study revealed some interesting findings, several limitations must be addressed. The researchers only looked at job posting aggregators and did not search for postings at individual institutions. Although this practice limited the overall number of advertisements found, it could also be seen as the process followed by many typical job searchers. Also, the number of advertisements found may have been limited by institutions not widely posting their position openings due to internal hires or the occasional cost of some job posting websites. Additionally, the researchers do not know if any of the job postings they found resulted in successful hires. Comparison of the desired qualifications listed in a job ad to the actual qualifications of the hired employee could be an avenue for future research.

Overall, the comparison between the two datasets revealed that many traditional responsibilities, requirements, and skills are found in both studies. However, the more widespread use of technology is extremely prevalent in the current advertisements. This study also found that cataloging managers are now being asked to take on more varied types of responsibilities, such as helping with disaster recovery efforts, that fall well outside traditional cataloging and management. Finally, the potential drop in required master's degrees and more responsibilities surrounding EDI could indicate that libraries want to be more thoughtful and open about the types of candidates they attract and hire. 
Although the overall landscape of libraries and cataloging has changed drastically since 2008, it remains grounded in traditional academic roots. The results presented in this article demonstrate transformations in the field, showcase how recent changes have affected cataloging manager positions, and provide insight into emerging factors that may influence these positions in the future, thus bestowing helpful information for any that seek to be a cataloging manager. 


\section{References}

Beall, J. (1991). Describing the foreign language skills of catalogers in academic libraries. Cataloging \& Classification Quarterly, 14(1), 39-47.

Beile, P. M., \& Adams, M. M. (2000). Other duties as assigned: Emerging trends in the academic library job market. College \& Research Libraries, 61(4), 336-347.

Chaudhry, A. S., \& Komathi, N. C. (2001). Requirements for cataloguing positions in the electronic environment. Technical Services Quarterly, 19(1), 1-23.

Copeland, A. W. (1997). The demand for serials catalogers: an analysis of job advertisements, 1980-1995. Serials Librarian, 32(1-2), 27-37.

Deeken, J., \& Thomas, D. (2006). Technical services job ads: Changes since 1995. College \& Research Libraries, 67(2), 136-145.

Dieckman, C. S. (2018). Qualifications for serials catalogers in the 21st century: A content analysis of job advertisements. Cataloging \& Classification Quarterly, 56(5-6), 487-506.

Ellero, N. P. (2014). Exploring library discovery positions: Are they emerging or converging? Journal of Web Librarianship, 8(4), 331-348.

Furuta, K. (1990). The impact of automation on professional catalogers. Information Technology \& Libraries, 9(3), 242-252.

Geckle, B. J., \& Nelson, D. N. (2017). Classifying librarians: Cataloger, taxonomist, metadatician? Serials Librarian, 72(1-4), 57-64.

Hall-Ellis, S. (2005). Descriptive impressions of entry-level cataloger positions as reflected in American Libraries, AutoCAT, and the Colorado State Library Jobline, 20002003. Cataloging \& Classification Quarterly, 40(2), 33-72.

Hall-Ellis, S. (2006a). Cataloging electronic resources and metadata: Employers' expectations as reflected in American Libraries and AutoCAT, 2000-2005. Journal of Education for Library \& Information Science, 47(1), 38-51.

Hall-Ellis, S. (2006b). Descriptive impressions of managerial and supervisory cataloger positions as reflected in American Libraries, AutoCAT, and the Colorado State Library Jobline, 2000-2004: A content analysis of education, competencies, and experience. Cataloging \& Classification Quarterly, 42(1), 55-92.

Hall-Ellis, S. (2008). Cataloger competencies: What do employers require? Cataloging \& Classification Quarterly, 46(3), 305-330. 
Hall-Ellis, S. (2015). Metadata competencies for entry-level positions: What employers expect as reflected in position descriptions, 2000-2013. Journal of Library Metadata, 15(2), 102134.

Han, M., \& Hswe, P. (2010). The evolving role of the metadata librarian: Competencies found in job descriptions. Library Resources \& Technical Services, 54(3), 129-141.

Harper, R. (2012). The collection and analysis of job advertisements: a review of research methodology. Library \& Information Research, 36(112), 29-54.

Hosoi, M. (2000). Cataloging positions in U.S. academic libraries: an analysis of job advertisements, 1999 [Master's paper, University of North Carolina at Chapel Hill]. Carolina Digital Repository. https://cdr.lib.unc.edu/concern/masters papers/wh246w887

Khurshid, Z. (2003). The impact of information technology on job requirements and qualifications for catalogers. Information Technology \& Libraries, 22(1), 18-21.

Kim, J., \& Angnakoon, P. (2016). Research using job advertisements: A methodological assessment. Library \& Information Science Research, 38(4), 327-335.

Kwasik, H. (2002). Qualifications for a serials librarian in an electronic environment. Serials Review, 28(1), 33-37.

Lack, A. R. (2001). People skills and technological mastery: What U.S. academic libraries require of catalogers in these areas [Master's paper, University of North Carolina at Chapel Hill]. Carolina Digital Repository. https://cdr.lib.unc.edu/concern/masters_papers/0v838437t

Lussky, J. P. (2008). Employer demands for cataloger and cataloger-like librarians and implications for LIS. Journal of Education for Library \& Information Science, 49(2), 116-127.

Mueller, C. J., \& Mering, M. V. (1991). Serials positions in U.S. academic libraries, 1980-1988: a survey of position announcements. Library Resources \& Technical Services, 35(4), 416-421.

Palmer, J. W. (1992). Job advertisements and cataloging skills. Journal of Education for Library \& Information Science, 33(1), 61-63.

Park, J., \& Lu, C. (2009). Metadata professionals: Roles and competencies as reflected in job announcements, 2003-2006. Cataloging \& Classification Quarterly, 47(2), 145-160.

Park, J., Lu, C., \& Marion, L. (2009). Cataloging professionals in the digital environment: A content analysis of job descriptions. Journal of the American Society for Information Science \& Technology, 60(4), 844-857. 
Reeves, R. K., \& Hahn, T. B. (2010). Job advertisements for recent graduates: Advising, curriculum, and job-seeking implications. Journal of Education for Library \& Information Science, 51(2), 103-119.

Reser, D. W., \& Schuneman, A. P. (1992). The academic library job market: a content analysis comparing public and technical services. College \& Research Libraries, 53(1), 49-59.

Russell, B. M. (2003). Looking for someone special: Special collections cataloging, 1980-2000 and beyond. Library Resources \& Technical Services, 47(4), 149-159.

Sibiya, P. T., \& Shongwe, M. M. (2018). A comparison of the cataloguing and classification curriculum and job requirements. Library Management, 39(6-7), 474-487.

Towsey, M. (1995). Does anyone out there want a cataloguer? Catalogue \& Index, (117), 4-5.

Towsey, M. (1997). Nice work if you can get it? A study of patterns and trends in cataloguing employment in the USA and the UK in the mid-1990s. Cataloging \& Classification Quarterly, 24(1-2), 61-79.

Turner, R. (2020). Analyzing cataloging job descriptions: Are cataloging jobs disappearing, changing, or merging? Cataloging \& Classification Quarterly, 58(6), 591-602.

$\mathrm{Xu}, \mathrm{H}$. (1996). The impact of automation on job requirements and qualifications for catalogers and reference librarians in academic libraries. Library Resources \& Technical Services, 40(1), 9-31.

Zhang, L. (2008). Foreign language skills and academic library job announcements: A survey and trends analysis, 1966-2006. Journal of Academic Librarianship, 34(4), 322-331.

Zhu, L. (2008). Head of cataloging positions in academic libraries: An analysis of job advertisements. Technical Services Quarterly, 25(4), 49-70.

Zhu, L. (2009). Employers' expectations for head of technical services positions in academic libraries. Library Collections, Acquisitions, \& Technical Services, 33(4), 123-131. 